Original Research Paper

\title{
Ekplorasi dan Penangkaran Bibit Rumput Laut (Eucheuma cottonii) di Perairan Teluk Ekas Lombok Timur
}

\author{
Nunik Cokrowati ${ }^{1}$, Nanda Diniarti ${ }^{1}$, Dewi Nur'aeni Setyowati ${ }^{1}$, Saptono Waspodo $^{1}$, M.Marzuki $^{1}$ \\ ${ }^{1}$ Program Studi Budidaya Perairan Fakultas Pertanian Universitas Mataram, Mataram, Indnesia
}

\section{Article history}

Received: 10 Januari 2019

Revised: 28 Januari 2019

Accepted: 12 Februari 2019

Published: 14 Februari 2019

*Corresponding Author:

Nunik Cokrowati,

Program Studi Budidaya

Perairan/Universitas

Mataram/Mataram, Indonesia; Email:

nunikcokrowati@unram.ac.id

\begin{abstract}
Abstrak: Tujuan dari penelitian ini adalah untuk mendapatkan bibit Eucheuma cottonii dari habitat aslinya di perairan Teluk Ekas dan menangkarkan bibit tersebut. Penelitian ini dilakukan di Teluk Ekas Lombok Timur Nusa Tenggara Barat. Metode yang digunakan pada penelitian ini adalah metode ekplorasi di perairan Teluk Ekas serta mendeskripsikan hasil pengamatan. Eucheuma cottonii yang berhasil di temukan dan di ekslporasi dari perairan Teluk Ekas, memiliki ciri morfologi lebih banyak memiliki bakal talus sehingga tampak sebagai duri-duri pada thalus. Talus keras dan kaku serta berwarna coklat kehijauan. Eucheuma cottoniidijumpai menempel pada batuan dan karang yang berada pada kisaran kedalaman 1 meter sampai dengan 1,5 meter. Eucheuma cottoniimenempel kuat pada subtrat sehingga sulit untuk diambil dengan tangan, harus menggunakan pisau atau alat pemotong lainnya. Eucheuma cottoniidapat ditangkarkan dan tumbuh dengan baik di perairan Teluk Ekas.
\end{abstract}

Kata kunci: Kappaphycus alvarezii, habitat, talus, karang, domestikasi

Abstract: The objective of this study was to obtain Eucheuma cottonii seeds from their natural habitat in Ekas Bay and breed these seeds. This research was conducted in Ekas Bay, Lombok Timur, Nusa Tenggara Barat. The method used in this study is the exploration method and description method. Eucheuma cottonii which has been found, has more morphological characteristics that have a talus so that it appears as thorns in the thalus. Talus is hard and stiff and has a greenish brown color. Eucheuma cottonii was found attached to rocks and corals which were in the range of 1 meter to 1.5 meters. Eucheuma cottonii sticks firmly to the substrate so that it is difficult to take by hand, must use a knife or other cutting tool. Eucheuma cottonii can be bred and grow well in Ekas Bay.

Keywords : Kappaphycus alvarezii, habitat, talus, coral, domestication

\section{Pendahuluan}

Rumput laut merupakan komoditas ekspor Indonesia, permintaan pasar terus menerus meningkat dari tahun ke tahun. Ask dan Azanza (2002) menjelaskan bahwa rumput laut dari jenis Eucheuma cottonii merupakan sumber utama hidrokolid karagenan yang penting secara komersial. Daerah penghasil rumput laut di Indonesia diantaranya adalah Nusa Tenggara Barat (NTB), Nusa Tenggara Timur, Bali, Sulawesi, Maluku dan Irian Jaya. NTB merupakan produsen rumput laut yang secara kontinyu berkontribusi pada pemenuhan permintaan pasar ekspor dan pasar nasional. Provinsi Nusa Tenggara Barat memiliki areal potensial untuk budidaya rumput laut seluas 25.206,00 ha. Areal tersebut tersebar pada daerah kabupaten Lombok Timur, Lombok Barat, Lombok Tengah, Sumbawa, Dompu, Bima, Kota Mataram, Kota Bima, Sumbawa Barat dan Lombok Utara. Produksi rumput laut NTB pada tahun 2013 tercatat sejumlah 620.115,6 ton. Jumlah Rumah Tangga Perikanan sebanyak 8.912 buah. (Dinas Kelautan dan Perikanan Provinsi NTB, 2017.

Produksi rumput laut terus menurun pada tahun tahun selanjutnya hingga pada tahun 2017 
secara nasional produksi rumput laut sejumlah 8,2 juta ton. Penurunan produksi tersebut disebabkan menurunnya kualitas bibit rumput laut, pergeseran minat pembudidaya rumput laut ke komoditas lain, kondisi cuaca yang tidak menentu dan rendahnya harga jual rumput laut kering. Rendahnya kualitas bibit rumput laut menyebabkan rumput laut tidak dapat tumbuh secara maksimal. Bibit yang tersedia saat ini dan digunakan oleh pembudidaya adalah bibit yang telah digunakan berulang sejak dimulainya budidaya rumput laut di NTB. Upaya pembaruan bibit telah dilakukan Dinas Kelautan dan Perikanan(DKP) NTB dengan menggunakan bibit hasil kultur jaringan. Cokrowati (2016) juga melakukan upaya perbaikan kualitas bibit dengan cara pemanfaatan ekstrak Sargassum aquifolium untuk meningkatkan pertumbuhan rumput. Kedua upaya tersebut memberikan kontribusi yang signifikan terhadap peningkatan produksi rumput laut NTB (Cokrowati, 2018). Perlu dilakukan upaya lainnya untuk memicu perbaikan dan pembaruan bibit rumput laut yang ada di NTB. Sehingga dapat meningkatkan produksi rumput laut di NTB secara kontinyu.Kadi (2004) menjelaskan bahwa rumput laut di Indonesia tersebar di beberapa wilayah yaitu Gracilaria $255 \mathrm{~km}^{2}$, Eucheuma $215 \mathrm{~km}^{2}$ dan Gelidium $47 \mathrm{~km}^{2}$. Eucheuma cottonii juga tumbuh di perairan Lombok dan Nusa Tenggara Barat. Tujuan penelitian ini adalah untuk mendapatkan bibit Eucheuma cottonii dari habitat aslinya di perairan Teluk Ekas dan menangkarkan bibit tersebut.

\section{Bahan dan Metode}

Penelitian ini dilaksanakan pada bulan April sampai dengan Oktober 2018 di perairan Teluk Ekas Desa Ekas Buana Kecamatan Jerowaru Kabupaten Lombok Timur Provinsi Nusa Tenggara Barat. Penelitian ini menggunakan metode ekplorasi di lapangan dan dilakukan pengamatan morfologi. Hasil pengamatan diuraikan secara deskriptif. Eksplorasi bibit Eucheuma cottonii dilakukan dengan cara mencari bibit tersebut pada dasar perairan Teluk Ekas. Penangkaran Eucheuma cottonii dilakukan pada rakit apung.

\section{Hasil dan Pembahasan}

Hasil eksplorasi bibit Eucheuma cottonii alami dari perairan Teluk Ekasadalah sebagaimana gambar dibawah ini. Eucheuma cottonii yang hidup alami diperairan Teluk Ekas memiliki morfologi thallus lebih keras, hal tersebut merupakan adaptasi thallus terhadap gerakan air yang lebih keras dan kedalaman yang lebih dalam dibanding pada rumput laut yang dibudidayakan. Eucheuma cottonii tersebut lebih banyak memiliki bakal thalus sehingga tampak sebagai duri-duri pada thalus. Azanza(1990) menjelaskan bahwa thallus Eucheuma berkisar antara 35 hingga $74 \mathrm{~cm}$. Cabang-cabang kecil hingga tulang rawan dalam konsistensi, mulai dari 7 hingga $9 \mathrm{~cm}$ panjangnya, dengan cabang kecil yang bersirip / keras. Diameter sel adalah sebagai berikut: 2-5 $\mu \mathrm{m}$ korteks luar, 30$196 \mu \mathrm{m}$ korteks dalam dan 20-45 $\mu \mathrm{m}$ medula. Aslan (1998) menjelaskan bahwa Eucheuma spp, memiliki ciri-ciri kerangka tubuh tanaman bulat silindris atau gepeng, berwarna merah, merahcoklat, hijau kuning, bercabang berselang tidak teratur, di atau trikhotomous, memiliki benjolanbenjolan (blunt nodule) dan duri-duri atau spines, dan subtansi talus "gelatinus" dan/atau "kartilagenus" lunak seperti tulang rawan. Eucheuma cottonii dijumpai menempel pada batuan dan karang yang berada pada kisaran kedalaman 1 meter sampai dengan 1,5 meter. Anggadiredja (2008) menjelaskan bahwa Eucheuma cottonii hidup pada perairan dengan gerakan air yang kontinyu dan pada kedalaman 0,5 meter sampai dengan1,5 meter. Pada penelitian ini, Eucheuma cottonii didapatkan dengan kondisi menempel kuat pada subtrat sehingga sulit untuk diambil dengan tangan, harus menggunakan pisau atau alat pemotong lainnya. Masyarakat tidak memanfaatkan Eucheuma cottonii tersebut, mereka lebih memilih membudidayakannya. Berikut adalah gambar Eucheuma cottonii yang masih dapat ditemukan di perairan teluk Ekas. 


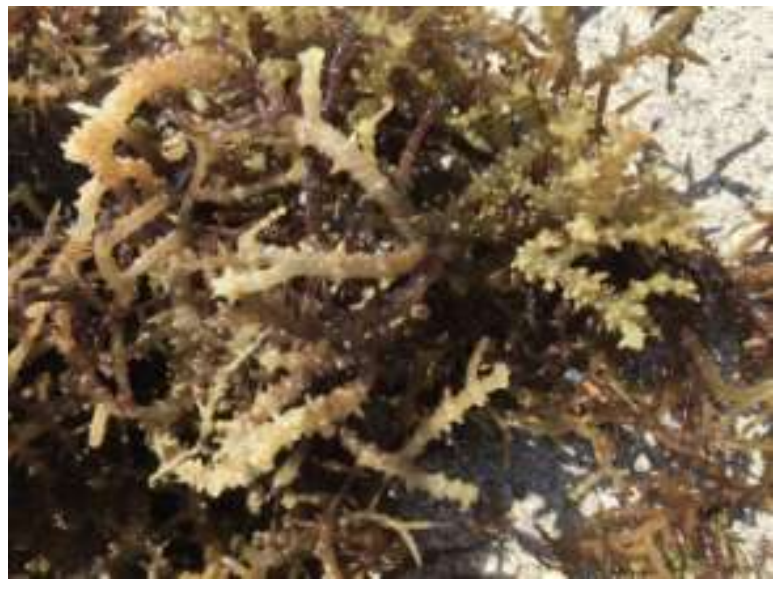

Gambar 1. Eucheuma cottonii yang hidup alami di Teluk Ekas

Sumber: Dokumentasi pribadi, 2018.

Budidaya dari hasil pengakaran bibit tersebut dilakukan sebagai upaya memberikan solusi terhadap ketersediaan bibit dengan kulitas baik dan terjangkau oleh pembudidaya. Sehingga pembudidaya tidak membeli bibit dari hasil budidaya dan tidak membeli bibit dari hasil kultur jaringan.

\section{Kesimpulan}

Bibit Eucheuma cottonii didapatkan dari habitat aslinya di Perairan Teluk Ekas Lombok Timur dan bibit tersebut telah ditangkarkan melalui kegiatan penelitian ini.

\section{Ucapan Terima Kasih}

Ucapan terima kasih disampaikan kepada Universitas Mataram yang telah mendanai penelitian ini melalui alokasi dana PNBP tahun anggaran 2018. Ucapan terima kasih juga disampaikan kepada pembudidaya rumput laut di Teluk Ekas Lombok Timur.

\section{Daftar Pustaka}

Azanza \& Corrales R. (1990). The farmed Eucheuma Species in Danajon Reef, Philippines:vegetative and reproductive structures. J. Appl. Phycol., 2:57-62.

Aslan \& La Ode M. (1998). Budidaya Rumput Laut. Penerbit Kanisius. Yogyakarta.
Ask EI. \& Azanza RV. (2002). Advances in cultivation technology of commercial eucheumatoid species: a review with suggestions for future research. Aquaculture, 206(3/4):257-277.

Anggadiredja, J.T. (2008). Rumput Laut: pembudidayaan, pengolahan \& pemasaran komoditas perikanan potensial. Penebar Swadaya. Jakarta.

Cokrowati, N. (2016). Buku Ajar Teknologi Budidaya Rumput Laut. Masyarakat Akuakultur Indonesia (MAI Publishing). Semarang.

Cokrowati, N. (2018). Peningkatan Produksi Rumput Laut Dengan Berbagai metode Budidaya. Laporan Hasil Penelitian Hibah Bersaing Sumberdana Ristekdikti. Universitas Mataram. Mataram Lombok Nusa Tenggara Barat.

Dinas Kelautan dan Perikanan Provinsi Nusa Tenggara Barat (2017). Statistik Perikanan Budidaya. Dinas Kelautan dan Perikanan Provinsi Nusa Tenggara Barat. Mataram Lombok Nusa Tenggara Barat.

Kadi, A. (2004). Potensi Rumput Laut di Beberapa Perairan Pantai Indonesia. Jurnal Oseana: XXIX (4) : 25-36 
Nunik et al, Jurnal Bologi Tropis, 19 (1) : 51 - 53 DOI: $10.29303 /$ jbt.v19i1.994 